\title{
Transatlantinis skilimas: ideologinès ištakos ir padariniai Vidurio ir Rytų Europai
}

\begin{abstract}
Dabartinis transatlantinis kivirčas išreiškia ne tik nesutarimus specifiniais tarptautinès politikos klausimais (pavyzdžiui, karas Irake). Antiamerikietišku nuotaiku pakilimas Europoje, kaip atrodo, liudija, jog transatlantinis aljansas patiria gilesnị skilimą. Keli skirtingi šio reiškinio aiškinimai nėra nesuderinami tarpusavyje, nes juos galima sujungti pasitelkus bendresnę hipotezę,kuri atkreipia dėmesi i i skirtingas ideologijas (jas daugmaž nusako individualizmo ir kolektyvizmo terminai), vyraujančiomis atitinkamai rytinëje ir vakarinëje Atlanto (galbūt net Lamanšo sąsiaurio) puséje. Šis skirtumas pasireiškia tiek šaliu vidaus politikoje, tiek ju veiksmuose tarptautinèje arenoje. Amerikiečių nepasitikëjimas didele valdžia ryškiai kontrastuoja su Europos etatizmu; amerikiečiu nenoras paklusti viršnacionalinei tvarkai kontrastuoja su europiečių pasirengimu pripažinti tokią tvarką. Vidurio ir Rytu Europos šalys palaikė Amerikos pusę Irako konflikto metu savo saugumo sumetimais; tačiau jos taip pat siekia glaudesnès Europos integracijos savo ekonominès pažangos sumetimais. Šie du tikslai gali pasirodyti nesuderinami, jeigu Europa nepajudès link individualistiškesnio ir dinamiškesnio anglosaksiškojo ekonominio modelio, skirtingo nuo to „,socialinès rinkos" modelio, kurị gina Vokietija ir Prancūzija.
\end{abstract}

\section{Ivadas}

Tarptautinės scenos stebėtojui turëjo pasirodyti keista, jog po baisiujų 9/11 išpuolių Amerikoje Vakarai nesusivienijo prieš naujają grèsmę. Priešingai, du pagrindiniai Vakaru pasaulio partneriai - JAV ir Vakarų Europa - pradejo vis mažiau sutarti dèl principiniu tarptautinès ir saugumo politikos gairiu ir vis labiau tolti vienas nuo kito daugeliu vidaus ir užsienio politikos klausimų. Išryškèjo pamatiniai požiūrių į geidžiamą tarptautinę tvarką ir ị dorojimosi su kylančiomis grésmėmis būdus skirtumai. Lengviausias ir paprasčiausias šiu nesutarimu paaiškinimas yra tas, kuris apeliuoja tik i politinių lyderių dviejose Atlanto pusèse ambicijų susikirtimą. Tačiau jo paviršutiniškumą liudija stebėtinas reiškinys - antiamerikanizmo proveržis Vakaru Europoje po 9/11 i̇vykiu. Būtent taip Vakarų Europos visuomenės ir jų intelektiniai lyderiai reagavo ị

* Dr. Algirdas Degutis - Kultūros, filosofijos ir meno instituto vyresnysis mokslinis darbuotojas. Adresas: Saltoniškių 58, Vilnius; tel. 273 7658; el. paštas: algirdas@ktl.mii.lt. 
karingus Amerikos pareiškimus ir karinius atsakus ị 9/11 išpuolị. Kas slypi už šio europietiškojo pacifizmo? Panagrinėsime keletą rimtesnių hipoteziu, mėginančių paaiškinti šį reiškinį ir rasti atsakymą į šị klausimą. Taip pat suformuluosime bendresnę hipotezę, kuri, kaip atrodo, leidžia paaiškinti beveik visus rimtesnius JAV ir Vakarų Europos nesutarimus. Paskutiniame skyriuje aptarsime transatlantinio skilimo padarinius Vidurio ir Rytų Europos šalims, telkdami dẻmesị i į̇ampą, kuri atsirado tarp šių šalių saugumo politikos ir ekonominės pažangos lūkesčiu, siejamų su Vakarų Europos „socialiniu modeliu“.

\section{Naujasis antiamerikanizmas Europoje}

Dabartinius Amerikos ir Vakarų Europos politikų nesutarimus tarptautinès politikos klausimais lydi antiamerikietišku nuotaiku stiprèjimas Vakaru Europos šalyse. Žinoma, antiamerikanizmas yra sena Europos elito nuostata; Europos aukštuomenė visada žvelge iš aukšto ir su panieka i i,komercinę“ ir "bedvasę" Ameriką. Tačiau praeityje šios nuostatos nelydëjo toks pat niekinantis Europos "masių" nusiteikimas. Paprasti europiečiai nejaute priešiškumo Amerikai. Tiesą sakant, daugelis jų teikè pirmenybę naujajam pasauliui, , ,atviru galimybiu šaliai“" ir balsavo už ją kojomis - masiškai migruodami į Ameriką. Padètis pasikeitè ir dabar net Europos „masès" tvirtai remia savo elitą, Amerikos atžvilgiu nusiteikusį įtariai ir priešiškai.

Kaip 2003 m. rašè Glennas Frankelis, Washington Post korespondentas Londone, "Vakarų Europos antiamerikanizmas plinta, stiprejja ir migruoja iš tradicinio prieglobsčio kairiujų intelektualu, akademikų bei kavinių bendruomenèse i politinį centrą. [...] Tokios šalys kaip Prancūzija, Vokietija ir Britanija, daugiau nei penketą dešimtmečių buvusios artimiausios Jungtinių Valstijų sąjungininkès, pradeda nuo mūsų tolti, stumiamos visuotinio susirūpinimo, baimès ir nepasitenkinimo bangos. Tiesioginiu taikiniu gali būti JAV politika Irako atžvilgiu, tačiau kylantis platesnis reiškinys yra baimè ir bodẻjimasis, kurį kelia Amerikos galia, jos politika ir jos motyvai ${ }^{\prime 1}$. Viešosios nuomonès apklausos, po Irako invazijos prabėgus metams, rodė, jog „,nepasitenkinimas Amerika ir jos politika sustiprëjo, o ne susilpnejjo. Požiūris ị Jungtines Valstijas Prancūzijoje ir Vokietijoje dabar ne mažiau neigiamas, nei buvo iškart po karo, o britų požiūris tapo daug kritiškesnis. [...] Vis labiau abejojama JAV karo prieš terorizmą motyvais, ir vis didesnis europiečiu procentas nori savo užsienio ir saugumo politiką matyti nepriklausomą nuo Jungtinių Valstijų“. Panaši apklausa 2005 m. parodè, jog Jungtines Valstijas palankiai vertinančių žmonių procentas Prancūzijoje sumažèjo nuo $62 \% 2000$ m. iki $37 \% 2004$ m. kovą (43\% 2005 m.) ir Vokietijoje nuo $78 \%$ iki 38 (41\% $2005 \mathrm{~m}$.) per tą patị laikotarpir ${ }^{2}$.

${ }^{1}$ Frankel G., „Anti-Americanism Moves to W. Europe's Political Mainstream“, Washington Post, Tuesday, February 11, 2003, p. A01.

${ }^{2}$ The Pew Survey Report of March 16, 2004, „A Year after Iraq War".

"The Pew Survey Report", „U.S. Image Up Slightly, But Still Negative“, 0623 2005, http:// pewglobal.org/reports/display.php?PageID=800, 15092005. 
Vakarų europiečiai dabar abejoja JAV gera valia, nepasitiki JAV užsienio politika, priešinasi JAV kišimuisi į Europos reikalus ir daugelis jų George'ą Bushą laiko didesne grėsme pasaulio taikai nei Kim-Jongilą. JAV istorikas Jamesas Ceaseris cituoja proamerikietišką (retas atvejis) prancūzų filosofą JeanFrançois Revelį: „Pašalinkite antiamerikanizmą ir nieko neliks iš šiandienos prancūzu politinès minties - nei kairëje, nei dešinëje", ir priduria, jog tas pat pasakytina apie Vokietiją ir apie beveik kiekvieną kitą Vakarų Europos šalį: „Antiamerikanizmas dabar viešpatauja kaip Europos intelektualu lingua fran$\mathrm{ca}^{\prime \prime 3}$. Ir juos tvirtai palaiko Europos "masès".

Tačiau kas yra antiamerikanizmas? Be abejo, jis turi būti skiriamas nuo kritikos Amerikos atžvilgiu. Pagal P. Hollanderio siūlomą apibrèžimą, antiamerikanizmas nusako „,specifinę nepasitenkinimo, bjaurèjimosi ar intensyvaus priešiškumo nuostatą, kurios ištakos gali [...] neturèti jokio ryšio nei su realiomis Amerikos visuomenės savybėmis, nei su JAV vykdoma užsienio politika“. Žodžiu, antiamerikanizmas nusako išankstini, daugiau ar mažiau nepagrịstą neigiamą nusistatymą, ,ppanašų į tokias priešiškumo nuostatas, kaip rasizmas, seksizmas arba antisemitizmas ${ }^{\prime \prime 4}$. Ar europietiškasis antiamerikanizmas atitinka šį apibrèžimą? Atrodo, kad taip. Ši nuostata Europoje išties yra tokia stipri, kad ji beveik neturi ryšio su kokia nors specifine JAV vykdoma politika; veikiau ji atspindi išankstinį atmetimą visko, ką JAV kur nors ar kada nors daro. Šiuo požiūriu Amerika nuolat trypia tarptautinę teisę, ",naikina torpedomis" tarptautinius susitarimus ir kelia pavojų stabilumui bei taikai visame pasaulyje. Amerika vykdo veidmainišką užsienio politiką ir vienašališkai naudojasi neprilygstama karine galia. Žodžiu, nepaisant jos retorikos apie kovą su "nenaudèlëmis valstybemis“, ji pati yra nenaudèlè valstybė tarptautinëje arenoje, jautis globalinëje porceliano parduotuveje. Amerikos vidaus politika taip pat suvokiama kaip iš esmès ydinga. Amerika yra savanaudiška, individualistinè, vien pelno besivaikanti visuomenè, apraizgiusi pasaulį savo godumo tinklais. Ji nesirūpina savo vargdieniais ir yra abejinga žmonijos vargams. „Europos gatvé“ linksta amerikiečius vaizduoti kaip aptukusius, rẻksmingus, neišauklètus vaikus, besibastančius po pasaulị su mirti sëjančiais ginklais.

Šis diskursas išreiškia gilų priešiškumą ir įtarumą Jungtinių Valstijų valdžios ir visuomenès atžvilgiu; Jungtines Valstijas jis vaizduoja kaip pasaulinị grobuoni, kurio veiksmus sąlygoja grobikiška jo prigimtis. Tai nèra tik kritinis, bet veikiau beveik religinio pasmerkimo diskursas. Tokios kritikos objektas yra nepataisomas ir nepagydomas, o jo kaltė neišperkama. Totalinė šio pobūdžio kritika nesuteikia savo objektui jokios galimybès pasitaisyti, pagerinti savo charakterị. Amerika gali būti kritikuojama dèl intervencionizmo ir čia pat vos atsikvèpus - dèl izoliacionizmo. Nèra tokio jos veikimo ar neveikimo, kuris falsifikuotų neigiamą nusistatymą jos atžvilgiu. Tokia kritika yra racionaliai nepaneigiama; jai nereikalinga logika arba jai pakanka konspiracijos teorijų logikos.

\footnotetext{
${ }^{3}$ Ceaser J., "A Genealogy of Anti-Americanism“, The Public Interest, Summer 2003.

${ }^{4}$ Hollander P., Anti-Americanism: Irrational and Rational, Transaction Publishers, 1995, p. lxxviii.
} 
Ši nuostata išties primena antisemitizmą. Amerikai metami kaltinimai sudaro panašu prieštaringų teiginių rinkinį: kaip ir žydai, amerikiečiai yra pernelyg religingi, bet kartu ir bedvasiai; šykštūs, bet kartu ir išlaidūs; nekultūringi, bet kartu savo kultūrą siekiantys primesti visam pasauliui; agresyvūs, bet kartu ir bailūs; kvaili, bet kartu ir itin gudrūs. Būtent šios kritikos dvasia Franzas Münteferingas, Vokietijos socialdemokratu partijos pirmininkas, palygino Vokietijoje veikiančius Amerikos finansininkus su Vokietijos bendroves užpuolusiais "skèriu pulkais" ${ }^{\prime 5}$ - palyginimu, kuriuo naudojosi naciai apibūdindami žydus. Šį išankstinị priešiškumą liudija daugybė publikaciju bei deklaracijų. Thierry Meyssanas savo bestseleryje ", 9/11: Didysis melas " dèsto visiškai beprotišką idèją: rugsëjo 11 dienos išpuolių aiškinimai yra suklastoti; faktiškai $\mathrm{T}$. Meyssanas įtaigauja, jog jie buvo suplanuoti dešiniujų klikos Amerikos vyriausybëje ir buvo iivykdyti Pentagono siekiant padidinti savo biudžetą. Knygos populiarumas liudija europietiškojo antiamerikanizmo iracionalumą, bet kartu ir patrauklumą. Populiari nauja knyga Vokietijoje yra Schwarzbuch USA (Juodoji knyga: JAV), kurioje autorius Ericas Frey'us beveik 500 puslapiuose surašė Amerikos „,nusikaltimus“ per visą jos istoriją pradedant nuo ,indènų sunaikinimo“.

Dažnai sakoma, jog George'as Bushas iššvaiste tą tarptautinès simpatijos kapitalą, kurị Amerika turëjo po 9/11 išpuolių. Tačiau iš tikruju jis neturëjo daug ko švaistyti. Dūmams dar kylant virš sugriuvusių dvynių bokštu, Europos intelektualai jau šventė tikrą Schadenfreude puotą. Garsus prancūzų filosofas Jeanas Baudrillardas skandalingai pareiškè: ,,Jie [teroristai] tai padarẻ, bet mes to norejome. [...] Terorizmas yra amoralus, bet jis yra atsakas i globalizavimą, kuris pats amoralus ${ }^{\text {"7 }}$. Kitas garsus prancūzų filosofas Jacquesas Derrida faktiškai èmėsi išpuolius teisinti 'dekonstruodamas' teroro sąvoką. J. Derrida svarsto: „,Turbūt darome klaidą paskubomis tardami, jog terorizmas yra visada sąmoningas, organizuotas, tikslingas ir apskaičiuotas: būna istorinių ir politinių 'situaciju', kai teroras veikia [...] tarsi pats savaime, vien kaip tam tikro aparato, susiklosčiusiu jègos santykiu padarinys, kai niekas [...] jo net nesuvokia ir nesijaučia už jị atsakingas". Ir toliau jis klausia: ar negali būti teroro be žudymo? ar negali būti taip, kad neveikimas, nenorëjimas žinoti, kad kažkur pasaulyje žmonės miršta nuo bado, nuo AIDS ir t. t., yra ,'daugiau ar mažiau' sąmoningos ir tikslingos teroristinès strategijos atmaina?"8. İtaigaujamas atsakymas, jog teroristu veiksmai buvo teisèta savigyna - atsakas ị Amerikos neveikimo terorą. Dar viena garsenybè, vokiečiu filosofas Jürgenas Habermasas, taip pat nesunkiai atranda 'giliąsias' teroristinių išpuoliu priežastis: „Politiškai nesutramdžius nežaboto kapitalizmo, pasaulį niokojanti visuomenès stratifikacijos problema liks neišsprendžiama. Pasaulio ekonominès raidos netolygumus būtina išlyginti dorojantis bent jau su destruktyviausiais ju padariniais - kalbu apie ištisu regionų ir žemynų nepriteklių ir skurdą. [...] [Priešingu atveju] Vakarai bus su-

\footnotetext{
${ }^{5}$ Interviu žurnale Bild am Sonntag, April 17, 2005.

611 septembre 2001, L'Effroyable Imposture, Chatou, Carnot, 2002.

${ }^{7}$ Baudrillard J., The Spirit of Terrorism (Verso), 2002, p. 134.

${ }^{8}$ Borradori G., Philosophy in a Time of Terror: Dialogues with Jürgen Habermas and Jacques Derrida, University of Chicago Press, 2003, p. 107-108.
} 
vokiami kaip engejjas ${ }^{\prime \prime}$. Kadangi būtent Amerika yra siejama su „nežaboto kapitalizmo“ "blogybėmis, išpuoliai prieš ją, net jeigu jie nepateisinami, yra visiškai suprantami.

Ši 'giliuju' teroro priežasčiu samprata atsiliepia Europos santykiams su Amerika. Dauguma amerikiečiu 9/11 išpuolius laiko nesutaikomo priešo ataka prieš Vakaru civilizaciją, o europiečiai linksta juos laikyti atsaku į Amerikos globaliajją politiką, dèl kurios jie tariasi niekuo dèti ir todèl santykiškai saugūs. Ir jie jaučiasi santykiškai saugūs, nes formaliai dar būdami Amerikos sajungininkais jie jau suvokia save kaip skirtingus nuo amerikiečių. Būtent ši savivoka - Europa yra ne Amerika - veikia tai, kaip jie traktuoja islamizmo grèsmę. Kadangi Amerika yra tokia ekspansionistinè, galinga ir arogantiška ir kadangi iš esmès ji yra išnaudotojiška kapitalistinè visuomenė, išpuoliai prieš ją tu, kurie jaučiasi jos pažeminti ar išnaudojami, yra suprantami ir tikètini. Radikalūs kairieji žengia dar vieną žingsni: jiems ' gilioji' teroro priežastis yra pati Amerika. Vyraujant šiai sampratai politinis europiečiu pasirinkimas apsiriboja alternatyva: sugėdinti Ameriką taip, kad ji pakeistų savo politiką arba atsiriboti nuo Amerikos siekiant išvengti panašiu išpuoliu prieš save. Kadangi beveik nėra šansų pasiekti pirmaji tikslą, lieka tik vienas pasirinkimas - atsiriboti nuo Amerikos. (Pavyzdžiu gali būti Ispanijos reakcija į teroro išpuolị Madride.) Amerikiečiai gali smerkti tokią politiką kaip kapituliaciją, kaip taikstymąsi su nepermaldaujamu priešu, kaip naujajį Miuncheną. Tačiau tiems europiečiams, kurie pačią Ameriką laiko valstybe nenaudèle, tokia strategija gali atrodyti racionaliausia. Faktiškai nėra bendros islamiškojo pavojaus priežasčiu sampratos, kuri padètu įveikti Europos ir Amerikos skilimą. Kadangi daugelis europiečiu šią grèsmę linksta sieti su grèsme, kurią kelia pati Amerika, tokia atsiribojimo politika jiems gali atrodyti visiškai racionali.

Susidaro įspūdis, jog europiečiai atrado stebètinai paprastą visų pasaulio nelaimių ir vargų paaiškinimą - „,versk kaltę Amerikai“. Bet kokia blogybė pasaulyje yra ịkaltis prieš Ameriką, nes ji yra jos veikimo arba neveikimo rezultatas. Kadangi Amerika yra tokia galinga, bet kartu tokia piktavalè, atrodo, jog ji negali imtis jokių veiksmų užsienyje, neprovokuojančių protestus tų, kurie permato jos klasta. Ir atrodo, jog negali būti tokio režimo,- kad ir kokio baisaus ir nežmoniško,- kurį mėgindama nuversti arba pakeisti Amerika nesusilauktų teisuoliško piktinimosi jos imperiniais siekiais, jos vienašališkumu ir „manichëjiška" arogancija. Tokia dabar yra vyraujanti Europos intelektualu bei gatviu protestuotoju, taip pat tokiu „Busho vanotojų“ Amerikoje, kaip Noamas Chomsky ir Michaelas Moore'as, nuostata.

Be abejo, čia galima pastebėti pragmatinį nenuoseklumą: kaltinant Ameriką dèl jos piktadarybiu turi būti postuluojama, jog Amerika, kitaip nei buvusi Sovietų Sajunga ar Šiaurès Korejja, reaguoja ị kaltinimus ir todèl nèra tokia piktavalé, kaip jos kritikai teigia. Verta atkreipti dèmesį i tai, kad masinių demonstraciju Vakarų Europoje prieš Amerikos karą Irake niekada nelydejjo kokios nors demonstracijos prieš Sadamo tironiją. O žiniasklaidos isterijos dèl tyčiojimosi iš

${ }^{9}$ Ten pat, p. 36. 
kalinių Abu-Graibo ar Gvantanamo kalëjimuose niekada nelydẻjo jos garsūs protestai dèl civiliu Irake nukirsdinimu. Susidaro įspūdis, kad susirūpinimas žmogaus teisėmis kyla tik tada, kai kritikams pasitaiko proga igelti Amerikai. Žmonèms Rytų arba Vidurio Europoje tai primena kitą įsidèmètiną faktą. Masinių demonstracijų Vakarų Europoje prieš JAV raketų dislokavimą aštuntajame dešimtmetyje niekada nelydëjo analogiškos demonstracijos prieš Sovietų tironiją. Be to, žmonėms Rytų ir Vidurio Europoje turi kelti nuostabą dar ir šis faktas: tai, kas Jürgeną Habermasą ir Jacques'ą Derridą paskatino Europos laikraščiuose paskelbti savo garsujį manifestą apie 'Europos viešojo forumo' gimimą, buvo masinès demonstracijos prieš Amerikos karą Irake $2003 \mathrm{~m}$. vasario $15^{10}$. Pasak ju, tai buvo „reikšmingiausias įvykis po Antrojo pasaulinio karo“. O tai reiškia, jog Berlyno sienos griuvimas, Sovietų Sajungos žlugimas ir jos viešpatavimo baigtis rytinèje Europos žemyno dalyje buvo kur kas mažiau reikšmingas ịvykis. Atrodo, jog, palyginti su Amerika, Sovietu Sajunga buvo nepakankamai bloga, kad mobilizuotu europiečius 'Europos viešajam forumui' sukurti. Ir atrodo, jog islamiškasis teroras Europai nèra toks baisus, kad ją suvienytų su Amerika prieš jị.

Dabartinis Europos antiamerikanizmas tik netiesiogiai siejasi su George'o W. Busho administracijos užsienio politika. Garsujį epitetą apie Ameriką, kaip arogantiškają̨ hyperpuissance, i̇ apyvartą paleido prancūzų Užsienio reikalu ministras Hubertas Védrine'as dar B. Clintono administracijos laikais. Antiglobalistų sajūdis, kurį nuo 1998 m. koordinuoja Attac organizacija Prancūzijoje, nuo pat pradžių pasižymèjo antiamerikanizmu. Vienas aktyviausiu jos nariu buvo garsus filosofas ir sociologas Pierre' as Bourdieu, aršus 'neoliberalizmo' kritikas. 1999 m. prancūzų antiglobalistų aktyvistas José Bové simbolinio vandalizmo aktu sugriovè McDonald's restoraną Prancūzijoje. Taigi europietiškas antiamerikanizmas jau seniai peržengia paprastos kritikos (pagrįstos ar nepagrịstos) ribas. Savo knygoje Antiamerikanizmas Revelis šią nuostatą vadina „,iracionaliu perviršimi“" ir ",apsėstimi“. Beveik neabejotina, kad ji neišnyks dabartiniam Baltujų rūmų šeimininkui pasitraukus į savo rančą ar pasikeitus Europos 'branduolio' lyderiams. Antagonizmo ištakos slypi gilesniame nei nesutarimu dèl tarptautinès politikos lygmenyje: jį skatina intelektinis klimatas, dabar vyraujantis Vakarų Europoje.

Europos antiamerikanizmas neišvengiamai turi savo kainą. Faktiškai jis duoda priešingus rezultatus, nei iš jo tikimasi. Net pagrịstą Amerikos politikos kritiką jis nuskandina priešiškų invektyvų lavinoje ir todèl skatina amerikiečius numoti ranka į bet kokius europiečių argumentus kaip visiškai beverčius, smerkti Europą kaip „,nukaršusią ir besipinančią po kojomis“" (Karlas Zinsmeisteris) arba nurašyti prancūzus kaip ,cheese-eating surrender monkeys“. Paradoksalu, bet įnirtingas antiamerikanizmas gali tik susilpninti Europos įtaką Amerikai.

\footnotetext{
10 „Nach dem Krieg: Die Wiedergeburt Europas“, Frankfurter Allgemeine Zeitung, 200305 31, "Europe: plaidoyer pour une politique extérieure commune", Libération, 20030531 - 20030601.
} 


\section{Aiškinimai: galių nelygybė ir priklausomybè}

Kaip paaiškinti dabartinį transatlantinį skilimą? Ar jis tẻra eilinis šeimyninis kivirčas iš esmès vieningoje Vakaru bendrijoje? Ar veikiau jis liudija gilesnius nesutarimus, kurie brendo jau seniai ir kurie tik aiškiau atsiskleidè Irako krizès metu? Robertas Kaganas ${ }^{11}$ iškèlè dabar jau išgarsëjusią hipotezę, kurią galima pritaikyti aiškinant dabartinį Europos antiamerikanizmą bei atsaką amerikietiškają eurofobiją. „Laikas nustoti vaizduotis, - rašo jis, - kad europiečiai ir amerikiečiai turi bendrą požiūrị į pasaulį ar kad jie gyvena tame pačiame pasaulyje“. Kaganas piešia šaržą, kur europiečiai vaizduojami kaip Veneros gyventojai, žengiantys ị kantiškaj̧i „,uždarą įstatymu, taisykliu, tarptautinių derybų ir tarptautinio bendradarbiavimo pasaulį“, o amerikiečiai vaizduojami kaip marsiečiai, įsitikinę tuo, jog karinè galia vis dar reikalinga Hobbeso džiunglèse, plytinčiose už Europos postmoderniojo rojaus sienų.

Pasak R. Kagano, ,transatlantinio skilimo priežastys yra gilios, jos klostèsi ilgai ir išliks ilgam". Pirmasis skilimo veiksnys yra Europos karinis silpnumas ir beprecedentè Amerikos karinè galia - veiksnys, kurį iš dalies sukūrẻ pati Amerika teikdama Europai saugumo garantiją Šaltojo karo laikais. Silpnumas turi psichologinių padarinių, jis skatina specifinę psichologinę nuostatą. Jeigu esate silpnas, stengsitès neišsikišti, sieksite taikių derybų bei susitarimu, apeliuosite į bendras normas bei taisykles, vengsite veiksmu, kurie kitiems galètu sukelti įtarimą, jog ketiname griebtis jègos. R. Kaganas pasitelkia įtaigią metaforą: žmogus miške, ginkluotas tik peiliu, kitaip reaguos i sẻlinančią mešką nei žmogus, ginkluotas šautuvu. Antrasis skilimo veiksnys yra Europos istorija, sukẻlusi esminių pokyčių europiečių pasaulěžiūroje. Šokiruoti ir sugėdinti savo pačių kruvinos praeities jie pradejjo taiką laikyti aukščiausiaja vertybe. Dabar jie siekia kantiškojo amžinosios taikos arba istorijos baigties pasaulio ir jie nori, kad kiti sektų jų taikios integracijos pavyzdžiu. Būdami silpni ir taikūs, jie stengiasi negirdèti riaumojimų iš džiunglių, plytinčių už jų rojaus, ir jaučiasi įžeisti ir pasipiktinę, jei kas nors demonstruoja savo jègą.

R. Kagano požiūriu, ši europietiškoji vizija pateisinama tik iš dalies. Europiečiai dabar išties susikūrẻ kantiškajị pasaulį Europos Sajungoje, kur ankstesniają suverenių valstybių anarchiją vis labiau keičia transnacionalinė ar net supranacionalinè organizacija - taiku pasauli, vis labiau valdomą teisés normu ir tarptautinių susitarimų. Tačiau aplinkybė, kurios jie nenori pripažinti, yra tai, kad ju taika ir saugumas galiausiai yra garantuojami Amerikos galybès. Ju kantiškasis pasaulis tapo galimas tik po gaubtu, skiriančiu ji nuo platesnio pasaulio, ir buvo faktiškai sukurtas tik todèl, kad jo sienas nuo grèsmių iš džiunglių gynė Amerikos Leviatanas.

Veneros ir Marso metaforoje galima ižzvelgti aliuziją į ‘moteriškos' Europos maištą prieš 'vyrišką' Ameriką - maištą, kurio griebiasi silpnesnioji, tačiau moraliai pakylètoji puse siekdama sutvardyti stipresniają pusę ir nukreipti jos veiksmus derama linkme. Tačiau Amerika negali patenkinti šio reikalavimo. Ji

${ }^{11}$ Kagan R., Apie roju ir galiq, Vilnius: Eugrimas, 2004. 
negali prisiimti atsakomybės už Vakarų pasaulio saugumą ir kartu savo sprendimus padaryti priklausomus nuo tu, kurie tokios atsakomybès neprisiima. Europos 'feministiniai' reikalavimai, net jeigu jie yra pagristi jos pačios mažame pasaulyje, negali būti priimtini Amerikai, veikiančiai plačiajame pasaulyje. Europiečiai gyvena iliuzijos pasaulyje. Jie tariasi esą autonomiški ir savarankiški nesuvokdami, jog be šalia stovinčios Amerikos jie būtų nutempti atgal į istoriją. Šis aiškinimas vis dèlto kelia tam tikrų problemų: ar europiečiai yra pacifistai dèl to, kad neturi pakankamai ginklu, ar veikiau priešingai - neturi pakankamai ginklų dèl to, kad yra pacifistai? R. Kaganas teikia pirmenybę pirmajam požiūriui, nors jis pripažįsta įtakas, veikiančias priešinga kryptimi. Be to, kai kuriu Europos ir Amerikos nesutarimu priežastį jis aiškina tuo, jog pasibaigus Šaltajam karui europiečiai mėgina apibrèžti „Europą“ kaip alternatyvą Amerikai užuot ieškoję naujo bendro „Vakaru“ apibrěžimo. Tačiau kodèl jie tai daro? R. Kagano siūlomas transatlantinio skilimo gydymo receptas, ne itin drąsus ir ne itin optimistiškas, yra dvejopas. Pirma, Europa turi skirti daugiau pinigu gynybai ir nustoti būti „kariniu nykštuku“. Antra, ji turi pripažinti, kad už postmoderniojo Europos pasaulio ribų vis dar plyti modernus ir iki-modernus pasaulis. Europiečiai gali išpažinti Kantą savo burbule, tačiau turi pripažinti Hobbesą platesniame pasaulyje, ir jie turi pripažinti Amerikai globalinio Leviatano vaidmenị. Išties galbūt turi pripažinti, bet ar pripažins?

Yra ir kitų skilimo aiškinimu, labiau pabrèžiančių jo psichologinį aspektą. Amerikietis karo istorikas ir publicistas Victoras Hansonas ir prancūzų politinis filosofas Pascalis Bruckneris Europos priešiškume Amerikai į̌zelgia „,priklausomybės sindromą" ir ",skolininko kompleksą“. Būdami Amerikos parūpinto saugumo išlaikytiniais europiečiai igijo psichologinį neapykantos išlaikytojui kompleksą. Būtent dèl to, kad Amerika gynė Europą, europiečiai vis mažiau dèmesio skyrè savo gynybai ir darèsi vis silpnesni. Ir kadangi silpnëjančiai Europai bus vis labiau reikalinga Jungtiniu Valstiju gynybinè parama, jie vis labiau nekęs Amerikos. Šešetą dešimtmečiu galiojanti Amerikos saugumo garantija Europai buvo strateginè klaida. Pamatinė NATO yda yra tai, kad daugeliui jos narių laisvasis pasaulis yra ",nemokami pietūs“", kad beveik visas sąskaitas apmoka viena šalis. Kaip bet kokia kita šalpa, saugumo šalpa sukuria kenksmingą ir sunkiai pagydomą jos gavejjo priklausomybę. Kaip sako P. Bruckneris, „,kuo labiau mes keikiame Jungtines Valstijas, tuo labiau mes nuo ju priklausome. Mes esame panašūs ị vaiką, kuris maištauja prieš savo tèvus siekdamas, kad jie niekada nepaliktu jo vieno ${ }^{\prime 12}$. Tiesą sakant, tai nėra nauja diagnozè. Dar 1982 m. britu istorikas Michaelas Howardas dare panašią išvadą: „Vakarų Europos šalys faktiškai išsižadèjo atsakomybès už savo pačių saugumą. Ju ginkluotosios pajėgos, kurios visada simbolizavo nacionalinės savimonès ir nepriklausomos egzistencijos siekị, tapo beveik periferinės, jų nekontroliuojamo branduolinés atgrasos mechanizmo dalimi ${ }^{\prime 13}$.

\footnotetext{
${ }_{12}$ Hanson V., „,Goodbye to Europe? “, Commentary, October 2002; Bruckner P., „Europe: Remorse and Exhaustion", Dissent, Spring 2003.

${ }^{13}$ Howard M., ,"Reassurance and Deterrence: Western Defense in the 1980s", Foreign Affairs vol. 61, no. 2, Winter 1982/1983, p. 312-313.
} 
Šiuo požiūriu postmoderniosios Europos aikštingumą paaiškina tas faktas, jog Vašingtonas ją atleido nuo pareigos rūpintis savo saugumu. Faktiškai Amerikos kariniu pajėgų buvimas tokiose šalyse kaip Vokietija yra gryna žala abiem pusėms: jis tik skatina oportunistinį pacifizmą ir antiamerikanizmą, kurstomą priklausomybės ir neapykantos globejjui komplekso. Amerikos atsisveikinimas ir pasitraukimas iš Europos būtu geriausias europietiškojo antiamerikanizmo problemos sprendimas ir jis galètų atverti naujų, brandesnių santykiu perspektyvą.

\section{Gilesnès priežastys: ideologinis skilimas}

Bet ar išties europietiškaji maištą prieš Ameriką galima paaiškinti vien galių nelygybės ir jos generuojamos psichologijos terminais (neapykanta globėjui, silpnejjantis grẻsmių suvokimas, pacifistinis mentalitetas)? O kas, jeigu, kaip teigia istorikas Tony Judtas, , ,europiečiai yra šykštūs savo gynybai ne dèl to, kad amerikiečiai garantavo jiems ịejjimą i amžinosios taikos pasali, o dẻl to, kad trečiame šio amžiaus ketvirtyje jie nusprendè skirti didžiulius pinigus brangioms (ir labai populiarioms) viešosioms paslaugoms". Globèjiškos valstybès plètra, socialinių (valstybinių) paslaugu gausėjimas vis labiau stūmè šalin privačias pastangas ir „,panašiai kaip viešasis sektorius išstūmė privačią iniciatyvą daugelyje nacionalinės politikos sričiu, taip ir kolektyvinio bendradarbiavimo ịprotis dabar formuoja Europos požiūrị į tarptautinius santykius ${ }^{\prime 14}$.

Smerkdami Amerikos vienašališkumą europiečiai išreiškia savajją vidaus politikos ir tarptautinių santykių viziją - viziją, kurią galima apibūdinti kaip kolektyvistinę, palyginti su kas labiau individualistine vizija, kuria vadovaujasi amerikiečiai. Šis skirtumas pasireiškia įvairiais būdais. Vienas yra tai, kokią santykinę vertę žmonès teikia individo nepriklausomybei ir 'savikliovai'. Amerikiečiai ją vertina labai aukštai; europiečiai, priešingai, labiau vertina 'solidarumą'. Nuošimtis amerikiečiu, manančiu, jog sẻkmę gyvenime lemia nuo jų nepriklausančios jègos, smuko nuo $41 \% 1988$ m. iki $32 \%$ dabar, tačiau taip manančių vokiečių nuošimtis išaugo nuo $59 \% 1991 \mathrm{~m}$. iki 68 \% dabar ${ }^{15}$. Kitas skirtumas yra tai, kad amerikiečiai noriai priima kapitalizmą, o verslo genijus šlovina panašiai kaip prancūzai garbina genialius menininkus bei intelektualus. Amerikoje gilias istorines šaknis turi antietatizmas, kurị sustiprino konservatyvioji Ronaldo Reagano revoliucija. Priešingai nei europiečiams, daugumai amerikiečiu valdžia nèra sprendimu šaltinis, veikiau ji pati yra problema. Su šia nuostata gali būti susijęs Amerikos religingumas, tas charakterio bruožas, kuris „skatina amerikiečius žvelgti i problemas per asmeninių dorybių ir ydų prizmę. Jis taip pat juos skatina visuomenės negeroves mėginti šalinti savanoriška veikla, o ne valdžios priemonèmis ${ }^{\prime \prime 16}$. Europiečių religingumas, priešingai, sparčiai

\footnotetext{
${ }^{14}$ Judt T., „Its Own Worst Enemy“, The New York Review of Books, August 15, 2002.

${ }^{15}$ Micklewait J., Wooldridge A., The Right Nation: Conservative Power in America, The Penguin

Press, 2004, p. 312

${ }^{16}$ Ten pat, p. 326.
} 
silpsta. Tiesą sakant, radikalus sekuliarizmas daugeliui ju pakeitè religiją. Europiečius taip pat glumina amerikiečiu patriotizmas ir nacionalizmas, nes dèl savo kruvinų karų patirties jie linksta nacionalizmą sieti su ksenofobija bei šovinizmu, o dabar jie mègina igyvendinti grandiozinį nacionalinio tapatumo ištirpinimo Europos supervalstybëje projektą.

Visa tai yra reikšmingi ideologiniai skirtumai ir atrodo, jog jie tampa vis ryškesni. Nuvalkiota frazė apie "bendras Vakarų vertybes" gali būti klaidinga, jeigu pamatinès vertybės - laisvė, žmogaus teisės ir t. t. - suvokiamos skirtingai dviejose Atlanto pusėse. Ir išties, kaip pastebi Tony Judtas, „,tai, kas europiečiams kelia didžiausią susirūpinimą Amerikoje, yra būtent tai, ką amerikiečiai laiko didžiausiu savo šalies privalumu: unikalų moralistinio religingumo, viešosios rūpybos minimumo ir rinkos laisvės maksimumo derini, , , ,amerikietiškajị gyvenimo būdą",-kurị papildo misionieriška užsienio politika, nukreipta i šių vertybiu ir šios praktikos eksportą ${ }^{\prime 17}$. Būtent šį amerikietiškajị gyvenimo būdą Gerhardas Schröderis niekinamai vadino amerikanische Verhältnisse, kuriu Europai nederètų imituoti.

Žinoma, kasdienė politika Amerikoje ir Europoje nèra taip radikaliai skirtinga: amerikiečiai yra gavę nemažai etatizmo dozių, ypač Lindono Johnsono epochoje, o europiečiai bent jau formaliai išpažissta liberaliają demokratiją. Tačiau ju giliosios nuostatos yra skirtingos, netgi priešingos. „Amerikiečiai, - rašo Pascalis Bruckneris, - laisvę supranta kaip „,svajonę“. Jie renkasi liberaliają demokratiją kaip geriausią iš visu sistemu, tuo tarpu daugelis europiečių liberalizmą priima tik todèl, kad patrauklesnès alternatyvos juos nuvylè"18. Amerikos viešosios nuomonės svorio centras yra kur kas toliau į dešinę (klasikinio liberalizmo linkme) nei bet kurioje kitoje išsivysčiusioje šalyje. Europa niekada neturëjo (išskyrus nebent M. Thatcher laikų Angliją) sajūidžio, analogiško tam, kuris pastaruosius 30 metu kilo ir stiprejo Amerikoje. O Amerika niekada neturejo rimtos partijos ar judëjimo, panašaus į europietiškają̨ socialdemokratiją. Kaip sako Micklethwaito ir Woolridge'o knygos pavadinimas, Amerika yra ",dešinioji šalis“.

Kadangi europiečiai Ameriką suvokia kaip begėdiškai kapitalistinę šali ir kadangi jie atmeta nežabotą kapitalizmą (pripažindami nebent sureguliuotą ir sutramdytą jo formą) reikalaudami vis platesnio ir gilesnio ,,socialinio teisingumo", šios dvi vizijos neišvengimai konfliktuoja. Neatsitiktinai antiamerikanizmas Europoje reiškiasi kartu su antiglobalizmu, dažnai dar ir tandeme su antisemitizmu - visi šie sajūdžiai yra aršiai antikapitalistiniai ir priešiški „,neoliberalizmui“", kurį skatina ir palaiko Amerika. Kaip pastebi J. Revelis, , pagrindinė antiamerikanizmo funkcija visada buvo ir yra liberalizmo diskreditavimas diskredituojant žymiausią jo įsikūnijimą. [...] Kova prieš globalizaciją yra apraiška daug senesnès kovos prieš liberalizmą, kurio svarbiausioji atstovè ir galingiausioji reiškëja yra Jungtinės Valstijos ${ }^{\prime 119}$. (Užkertant kelią painiavai reikia pabrèžti, jog žodi „liberalizmas“ J. Revelis vartoja europietiškaja prasme; Amerikoje šią termino prasmę daugmaž išreiškia 'konservatizmas'.)

${ }^{17}$ Judt T., "It's the anti-American Way", Financial Review, April 17, 2003.

${ }^{18}$ Bruckner, ten pat.

${ }^{19}$ Revel J. F, Anti-Americanism, Encounter Books, 2003, p. 12, 31. 
Negalima sakyti, jog prancūzai ir vokiečiai, ar net britai, buvo karšti Amerikos simpatikai Šaltojo karo laikais. Kol Sovietų imperija kẻlè grėsmę Vakaru Europai savo raketomis ir kariuomene jos pašonèje, Vakarų vienybė turejjo labai pragmatišką motyvą. Tačiau kai šis pavojus išnyko, transatlantinės harmonijos paskatos pradėjo silpnèti, o ideologiniai skirtumai vis labiau ryškèti. Yra taip pat ryšys tarp Berlyno sienos griuvimo ir įvairių 'anti' judejjimų atsiradimo kairiajame politinio spektro sparne. Po 'realaus socializmo' žlugimo ir marksizmo diskreditacijos kairieji prarado pozityvų savo vienybės pagrindą. Nors jie gali apeliuoti į tokias miglotas sąvokas, kaip „,socialinis teisingumas“ ar ",pažangos vertybès“" tikrasis kairiujų vienybės rišiklis šiandien (tiek Europoje, tiek Amerikoje) yra neapykanta Jungtinèms Valstijoms, įkūnijančioms sistemą, kurią jie laiko ydinga, net jeigu ir neiveikiama ${ }^{20}$. Amerikietiškas arba, plačiau, ,, anglosaksiškas" "kapitalizmo modelis atrodo kultūriškai ir filosofiškai svetimas Europos žemyno mentalitetui. Jis suvokiamas kaip grèsmė europietiškajam geros visuomenès idealui. Neatsitiktinai „,socialinio modelio“ - smulkmeniškai reguliuojamos, korporatistinès ekonomikos ir valstybinio paternalizmo - gynimas Europoje tapo pastanga, vienijančia profsajungas, antiglobalistus bei antiamerikietiškaji gaivalą ${ }^{21}$.

Šių geros visuomenès vizijų skirtumai pasireiškia ir tarptautinių santykių srityje. Viena vertus, Amerikos vidaus reikalų individualizmas natūraliai transformuojasi į vienašališkumą tarptautinëje arenoje. Amerikiečiu įsitikinimas, jog vidaus gyvenime piliečiams geriausia palikti maksimalią veikimo laisvę pripažistant valdžiai tik labai ribotas intervencijos sritis, formuoja jų požiūri ir į tarptautinius santykius. Vadovavimasis ,išèjimo“, o ne „balsavimo“ strategija (Hirschmano terminai), dalyvavimą tarptautinëje bendruomenëje traktuojant kaip laisvo pasirinkimo dalyką ir visada pasiliekant galimybę iš jos pasitraukti, yra analogiškas Amerikos individualistinei praktikai vidaus reikaluose. Kita vertus, Europos tarptautinis „daugiašališkumas“ yra vidaus kolektyvizmo - „balsavimo“ "strategijos - apraiška tarptautiniame lygmenyje. Pamatinè idèja yra kolektyvinè atsakomybė, jungtinè veikla, klusnumas aukštesniam autoritetui - valstybei (vidaus reikaluose) arba ",tarptautinei bendruomenei“ (globaliu mastu).

Transatlantiniai nesutarimai tarptautinëje arenoje iš esmès tėra padidinti nesutarimai dèl vidaus politikos. Čia konfliktuoja dvi ideologijos. Viena yra grindžiama prielaida, kad individai ir tautos turi kliautis pirmiausia patys savimi, gali laisvai stiprinti savo galias ir jėgas (kurdami, jei pageidauja, ,,savanorių koalicijas") - minimaliai kišantis ị jų reikalus nacionaliniams ar globaliems autoritetams. Atitinkamai „daugiašališkumas“ turi skirtingas prasmes dviejose Atlanto pusėse. Dauguma europiečių tiki tuo, ką Robertas Kaganas vadina principiniu daugiašališkumu. Ju požiūriu, tarptautinis pritarimas (suteikiamas, pa-

${ }^{20}$ Markovits A. S., ",The European and American Left since 1945“, Dissent, Winter 2005, p. 5-14.

${ }^{21}$ Dvi naujos knygos, kuriose ginamas europietiškasis ir "anglosaksiškas“, modelis yra atitinkamai, Rifkin J., The European Dream: How Europe's Vision of the Future is Quietly Eclipsing the American Dream, Tarcher/Penguin, 2004; Gersemann O., Cowboy Capitalism: European Myths, American Reality, CATO Institute, 2004. 
vyzdžiui, JT Saugumo tarybos) yra ne tik priemonè tikslui pasiekti, bet tikslas pats savaime, bet kokių veiksmų tarptautinëje arenoje teisètumo condition sine qua non. Net jeigu Jungtinès Valstijos būtų visiškai teisios dẻl Irako, europiečiai vis vien manytu, kad Jungtinių Valstijų intervencija būtų neteisèta nesant tarptautinės bendruomenės pritarimo. Amerikiečiai, priešingai, nėra principiniai daugiašalininkai. Daugiašališkumas jiems tèra instrumentinè vertybė. Ju formulè, atrasta dar B. Clintono administracijos laikais, yra „daugiašališkumas jeigu galimas, vienašališkumas - jeigu būtinas". Richardas Haasas, buvęs aukštas pareigūnas Vašingtone, taip išreiškè šią idejją: , ,Jokia organizacija, net Jungtinès Tautos, neturi monopolio teisètumo klausimu; teisètumas priklauso nuo to, kokiais argumentais grindžiamas tam tikras veiksmas ir kokiais būdais jis vykdomas “22.

Ši nuostata kelia nerimą europiečiams. Jie jau perleido daugelį savo valstybinio suverenumo galių supranacionalinėms Europos Sajungos organizacijoms, ir dabar Europos gyvenimą vis labiau reglamentuoja tokia valdžia, kuri nėra kontroliuojama nacionaliniu lygiu, kitaip sakant, veikia post-nacionalinis Europos daugiašališkumo režimas. Kaip pabrèžè Javieras Solana, daugiašališkumo reikalavimas nėra europiečių gudrybė siekiant tarptautinėmis sutartimis surišti Amerikos Guliverį: „Europiečiu išpažįstamas daugiašališkumas yra ju i̊sitikinimo dalykas, o ne piktybinè strategija. Patirtis mums sako, jog dalijimasis suverenumu (sharing) yra suverenumo stiprinimas. Netiksliai cituojant sero Winstono Churchillio aforizmą, daugiašališkumas yra blogiausia tarptautinės bendruomenès valdymo forma, išskyrus visas kitas, kurios jau buvo išmėgintos ${ }^{\text {“23 }}$. Tad nenuostabu, kad Donaldo Rumsfeldo tezè, jog „,blogiausia, ką galima padaryti, - tai leisti koalicijai apibrèžti misiją", sukèlè pasipiktinimą Europoje. Amerikiečiu požiūriu, jeigu tarptautinès institucijos apskritai turi kokią nors teisètą galią, tai tik „,tą galią, kurią joms suteikia nacionalinès valstybès savo suderètais susitarimais. [...] Europiečiai, priešingai, yra linkę manyti, jog demokratinis teisètumas nusileidžia iš viršaus, platesnès tarptautinės bendruomenės valia, pranokstančia bet kurios atskiros nacionalinès valstybės valią̨ ${ }^{\prime 24}$. Amerikiečiai linksta ị individualizmą, europiečiai - ị kolektyvizmą. Kolektyvinè nuostata tarptautiniame lygmenyje reiškia, jog tik kolektyvai turi teisę apibrèžti misijas: misijos turi būti distiliuojamos iš kolektyvinès valios arba turi gauti jos pritarimą. Kolektyvistui veiksmas yra neteisètas, jeigu nèra sankcionuotas kolektyvo; individualistui veiksmas yra teisètas, jeigu nèra jo neteisètumo įrodymo.

Taigi Europa ir Amerika turi skirtingas veiksmo atsakomybès tarptautinëje politikoje sampratas. Per keletą pastarujų dešimtmečių europiečiai vykdè projektą, demontuojantį nacionalinę valstybę ir denacionalizuojantị politinį gyvenimą, ir būtent dèl to Amerikos nacionalizmą ir patriotizmą jie yra linkę laiky-

${ }^{22}$ Haas R., "Sovereignty: existing rights, evolving responsibilities", remarks to the School of Foreign Service and the Mortara Center of International Studies, Georgetown University, 14 January, 2003.

${ }^{23}$ Solana J., "Europe and America: partners of choice“, speech to the annual dinner of the Foreign Policy Association, New York, 7 May, 2003.

${ }^{24}$ Fukuyama F., „The West May be Cracking: America vs. The Rest", New Perspectives Quarterly vol. 21, no. 3, Summer 2004. 
ti anachronizmu. Ir priešingai, daugelis amerikiečių žvelgia ị šị europietiškajji projektą su įtarumu, įžvelgdami jame klastingą sumanymą realizuoti socialdemokratinę viziją tarptautiniu ir galiausiai globaliu lygiu. Jiems kelia nerimą tai, kad europietiškasis politinio valdymo modelis galiausiai veda į socialistini „transnacionalinị progresyvizmą" ir ị viršnacionalinių organizacijų - „akronimijos" - viešpatiją ${ }^{25}$.

Pasak Russelo Bermano, , ,pasirinkimas tarp vienašališkumo ir daugiašališkumo nurodo kažką daugiau nei tarptautinių santykių subtilybes. Vyksta dviejų fundamentaliai skirtingu pasaulěžiūru konfliktas. Daugiašališkumas, pagal apibrèžimą, reiškia individo prerogatyvų panaikinimą ir jis implikuoja atsakomybės perleidimą komitetų režimams, o tai, kaip parodè politikos teoretikè Hannah Arendtè, yra tokia atsakomybè, kurios niekas neneša. [...] Tiek vidaus politikoje, tiek tarptautiniuose reikaluose jo padarinys yra egoizmo įveika. Tuo tarpu Jungtinių Valstijų sąsaja su vienašališkumu išreiškia visiškai kitokią laisvès sampratą - laisvę, kuri nepriklauso nei nuo valstybès, nei nuo supervalstybès.“" ${ }^{26}$ Panašiai kalba Francis Fukuyama: „Visais šiais požiūriais - rūpybos, nusikalstamumo, verslo reguliavimo, švietimo ar užsienio politikos klausimais - egzistuoja tvarūs skirtumai, kurie Ameriką daro nepanašią i jokią kitą šali. Amerika yra kur kas labiau antietatistinè, individualistinė, labiau palaikanti laissez faire ir labiau egalitarinė nei bet kuri kita demokratija"27. Abu autoriai pabrèžia anglosaksiškąją laisvès idèją: laisvè priklauso individams, ji nėra privilegija, kurią individams suteikia kolektyvai. Pastaruoju metu apskritai dažnai pabrěžiamas šios idèjos kontrastas su Europos kontinentine (prancūzų) tradicija, kur tik ,,bendra valia“ yra tas teisètumo šaltinis, kuris suteikia veiksmų laisvę individams ir ju grupèms. Amerikos politinè tradicija kyla iš vieno konkretaus šaltinio - iš anglu klasikinio liberalizmo. Būtent todèl jos politinė kultūra yra kur kas monolitiškesnè nei toji, kuria gali pasiremti europiečiai ${ }^{28}$. Amerikoje nèra jokio atitikmens europietiškai dešiniujų-kairiujų takoskyrai. Europietiškojo tipo socialdemokratija Amerikoje niekada nepasiekè ir vargiai ar kada nors pasieks plataus politinio pripažinimo aukštumas. Kaip rašo Dešiniosios šalies autoriai, ,'Amerikos viešosios nuomonès svorio centras yra smarkiai pasislinkęs į dešinę - ir visam pasauliui derètu išsiaiškinti, ką tai reiškia“229.

\footnotetext{
${ }^{25}$ Fonte J., „,Liberal Democracy vs. Transnational Progressivism: The Future of the Ideological Civil War Within the West", Orbis, Summer 2002; O'Sullivan J., "Gulliver's travails: The U.S. in the post-Cold-War world“", The New Criterion, Vol. 23 No. 2, October 2004.

${ }^{26}$ Berman R., Anti-Americanism in Europe: A Cultural Problem, Hoover Institution, 2004, p. 79-80.

${ }^{27}$ Fukuyama, (24 išnaša).

${ }^{28}$ Pastaruoju metu pasirodė ištisas srautas veikalu, kuriuose mėginama apibrėžti skirtumą tarp Europos ir Amerikos (tiksliau, anglosaksiškosios) politinès tradicijos: MacFarlane A., The Riddle of the Modern World: Of Liberty, Wealth and Equality, Palgrave Macmillan, 2002 Himmelfarb G., The Roads to Modernity : The British, French, and American Enlightenments, Knopf, 2004; Huntington S., Who Are We: The Challenges to America's National Identity, Simon and Schuster, 2004; Bennett J. C., The Anglosphere Challenge: Why the English-Speaking Nations Will Lead the Way in the Twenty-First Century, Rowman \& Littlefield Publishers, Inc., 2004.

${ }^{29}$ Micklewait J., Wooldridge A., (15 išnaša) p. 11.
} 
Tiek kultūriniam elitui, tiek platesnių kultūrinių vertybių lygmenyje Vakarų Europos ir Amerikos skirtumai yra labai reikšmingi ir turi rimtu politiniu padarinių. Skirtingos laisvės sąvokos, skirtingos geros visuomenės vizijos formuoja skirtingus požiūrius ị tai, kaip jos gali būti įgyvendintos platesniame pasaulyje. Šie ideologiniai skirtumai geriau paaiškina dabartinius transatlantinius nesutarimus nei galių nelygybė, kuri veikiausiai yra ideologinio Vakaru skilimo padarinys, o ne jo priežastis.

\section{Skilimo ataidai: senoji ir nauji Europa}

Nieko nuostabaus, kad antiamerikanizmas beveik niekaip nepasireiške neseniai išsivadavusiose Vidurio Europos ir Baltijos šalyse. Visos Vidurio Europos valstybės ir ypač Baltijos šalys suvokia, jog tik galingosios Amerikos ryžtas priešstatoje su „,blogio imperija“ joms padejjo atgauti savo nepriklausomybę. Ši valstybinès nepriklausomybès idèja vis dar išlieka gyvybinga šiame regione ir ji puikiai rezonuoja su Amerikos nacionalizmu. Tačiau pastaruoju metu Vidurio ir Rytų Europos nacionalizmas susiduria su rimtomis problemomis.

Atrodo, jog beveik visos Vidurio ir Rytu Europos šalys susiduria su dilema dabartinëje transatlantinių santykių krizèje ${ }^{30}$. Visu jų postkomunistinės politikos tikslas buvo integravimasis į europietiškas ir transatlantines struktūras (ES ir NATO). Jos pasitiki NATO kaip patikima jų saugumo garantija, bet tik todèl, kad narystė šioje organizacijoje reiškia glaudžius ryšius su JAV - galingiausia jos nare. Ir jos siekia gerų santykių su JAV, nes netiki, jog „,branduolio“ Europa (net pati priklausydama NATO) galètų ar norètų ateiti joms i i pagalbą pavojaus atveju. Sis jų skepticizmas yra visiškai pagrịstas. Jos turëjo progu įitikinti kartotinomis Europos nesèkmėmis dorojantis su krizėmis savo pačios kieme - ryžtingajai Amerikai nuolat atskubant jai i pagalbą. Jas glumino Prancūzijos ir Vokietijos bendradarbiavimas su Rusija (ir Kinija) blokuojant amerikiečiu pastangas gauti Saugumo tarybos pritarimą invazijai į Iraką. Jos taip pat gali padaryti skeptiškas išvadas iš tokių faktu, jog vokiečiai Vladimirą Putiną vertina palankiau nei George’ą W. Bushą.

Palaikydamos Ameriką Irako klausimu Vidurio ir Rytu Europos šalys (kartu su Britanija, Danija ir Nyderlandais) faktiškai sužlugde Vokietijos ir Prancūzijos pastangas pasukti ES užsienio politiką antiamerikanizmo linkme. Ir jos nesileido ịbauginamos Paryžiaus ir Berlyno. The Washington Times skelbė, jog "Vidurio ir Rytu Europos šalys tapo pagrindiniais Amerikos sajungininkais Europoje $^{\prime \prime 31}$. Taigi transatlantinis skilimas pasireiškẻ kaip skilimas pačioje Europoje. Saugumo klausimais Europa akivaizdžiai pasidalino i proamerikietiškas ir antiamerikietiškas stovyklas, i ‘naujają ir 'senająa' Europą - taip akivaizdžiai, kad The Economist iškèle klausimą, ar NATO ir Europos sajunga yra partnerès ar varžovès ${ }^{32}$.

30 Budryte D., „The Dilemma of 'Dual Loyalty': Lithuania and Transatlantic Tensions" in Old Europe, New Europe and the US, ed. by Tom Lansford, Blagovest Tashev, Ashgate, 2005.

${ }_{31}$ "A Ticket to the New Europe", Washington Times, February 9, 2003, p. 4.

32 "NATO and the European Union“, The Economist, February 26, 2005. 
Tačiau, kita vertus, „,naujieji“ europiečiai Europos sajungą laiko pagrindiniu instrumentu savo ekonominei pažangai. Ši dvejopa nuostata - Amerikos palaikymas saugumo sumetimais ir šliejimasis prie Europos Sajungos ekonominiais sumetimais - gali tapti prieštaringa ir neigyvendinama, jeigu Europos Sajunga vystysis kaip atsvara Amerikai - o būtent taip jos ateitị isivaizduoja dabartinis Vokietijos ir Prancūzijos tandemas. Tad atrodo, jog "naujieji“ europiečiai išties susiduria su dilema: arba efektyvus saugumas (ir aljansas su Amerika), arba ekonominé pažanga (aljansas su vokiečių ir prancūzų tandemu Europos sajungoje).

Tačiau ar tai yra reali dilema? Ji yra reali tik priimant prielaida,,jog ES, kaip politinè sajunga, yra būtina "naujosios“ Europos ekonominès pažangos sąlyga. Kaip tik šia prielaida galima suabejoti. Toli gražu nèra akivaizdu, kad „vis glaudesnè Europa“, grindžiama jos „socialiniu modeliu“, geriausiai pasitarnautu ekonominiams šalių naujokių interesams. Tiesą sakant, gali kilti abejoniu, ar glaudesnè Europa joms apskritai naudinga. Tariamoji dilema remiasi idejja, kad Europos „socialinis modelis“ yra gyvybingas ir kad jis, net būdamas ekonomiškai mažiau efektyvus, garantuoja didesnį „,socialinị saugumą" nei anglosaksiškas modelis. Tačiau ši prielaida vis labiau tampa kritikos objektu. Pasak britu istoriko Paulo Johnsono, „ES ekonominę filosofiją, jeigu ji apskritai tokią turi, nusako vienas žodis - „konvergencija“. Siekiama visas nacionalines ekonomikas užtempti ant vieningo tobulo modelio kurpaliaus. O tai yra tobulas receptas stagnacijai. Tai, kas varo į priekị kapitalistinę sistemą, kas palaiko ekonomikos dinamizmą, yra būtent nonkonformizmas, visa, kas nauja, neiprasta, ekscentriška, netikèta, kas kyla iš neišsemiamo žmogiškosios prigimties išradingumo" ${ }^{1 / 33}$. Perdètas reglamentavimas ir konformizmas jungtyje su monopolinėmis profesinių sajungų galiomis kelia stagnaciją ir nedarbą „branduolio“ Europai paversdamas niekais saugumo ir solidarumo pažadus ${ }^{34}$. Padètį dar labiau apsunkina gresiantis pensinio aprūpinimo sistemos žlugimas Europos populiacijai sparčiai senstant, o gimstamumo lygiui nusmukus daug žemiau už paprastos reprodukcijos lygị.

Kyla nerimas, net Vokietijoje ir Prancūzijoje, kad ,,socialinis modelis“ turi esminiu ydų ir kad reikalingos reformos, kurios jį priartintų prie „,anglosaksiškojo" modelio. Faktiškai negalavimai, nuo kurių dabar kenčia "branduolio“ Europa, yra panašūs į tuos, kurie buvo apnikę pačias JAV ir Britaniją aštuntajame dešimtmetyje. Britai ir mažesniu mastu amerikiečiai jau išbandẻ savuosius „socialinius modelius" ir ịsitikino ju ydingumu. Dabar jau plačiai pripažįstama, jog būtent rinkos liberalizavimo reformos, kurias pradèjo R. Reaganas ir M. Thatcher, nutraukè stagnacijos ir nuosmukio procesą anglosaksų valdose. Nieko nuostabaus, kad pastaraji ketvirtį amžiaus Jungtinių Valstijų ir Jungtinès Karalystès ekonominio augimo tempai buvo dvigubai didesni už Vokietijos, Prancūzijos ir Italijos; o nedarbo lygis JAV ir Jungtinejje Karalystëje nesiekia $5 \%$, kai tuo tarpu Vokietijoje ir Prancūzijoje jis perkopia dviženklius skaičius.

Analogiškas abejones „,socialinio modelio“" gyvybingumu reiškia Čekijos Prezidentas Vaclavas Klausas, kuris pasiremdamas ekonomisto Nobelio premi-

\footnotetext{
33 Johnson P., "What Europe Really Needs“, The Wall Street Journal, Friday, June 17, 2005.

34 Gersemann ( 21 išnaša) p. 2, 3.
} 
jos laureato Friedricho Hayeko argumentais atkreipia dèmesį į biurokratinès centralizacijos pavojus politiniame darinyje, jungiančiame daugybę skirtingu tautu. Pasak V. Klauso, ,"integracija“, suvokiama kaip rinkų atvirumas, yra geras dalykas, nes skatina konkurenciją ir apriboja valstybinio intervencionizmo galias, tačiau „unifikacija“ yra neabejotinai žalinga ekonomikai. Be to, ji yra pavojinga, nes mégina sukurti demokratinį vienetą ten, kur nèra ",demoso" tokiam suvienijimui ${ }^{35}$. Martas Laaras, žinomas estu politikas, išreiškẻ panašu požiūrị reaguodamas i i garsujį Prezidento Chiraco akibrokštą: „Europai laikas keistis. Ji turi tapti dinamiškesnè, ryžtingesnè, konkurencingesnè, atviresnè ir labiau orientuota į ateitį. Europos tautos gali išsaugoti savo unikalų tapatumą net būdamos atviros viena kitai. Būtent tai yra tikroji Europos tapatybè - ne kokia nors susigalvota vienybe ${ }^{\text {“36 }}$. Šių kritikos balsų daugëja.

Vis dèlto kaip galima turèti iš ES ekonominès naudos ir kartu išvengti "vis glaudesnès vienybės“ kaštų? Davidas Hannanas, britų konservatyvus parlamentaras, siūlo sprendimą. Britanija, jo požiūriu, turi išsaugoti prekybinius ryšius su ES, palaikyti glaudžius tarpvyriausybinius santykius, tačiau nepasiduoti politinei asimiliacijai. Tai nèra utopinis projektas. Pažvelkime į EFTA (Europos laisvosios prekybos asociacija), kuriai priklauso Norvegija, Šveicarija, Islandija ir Lichtenšteinas: šios šalys „,naudojasi visomis keturiomis vieningos rinkos laisvèmis: laisvu prekių, paslaugu, žmonių ir kapitalo judèjimu. Tačiau jos pasilieka už Bendrosios žemès ūkio politikos ribų, pačios kontroliuoja savo sienas, pačios sprendžia žmogaus teisių klausimus, jos gali laisvai derètis dèl prekybinių santykių su ES nepriklausančiomis šalimis ir jos moka tik simbolinę sumą į ES biudžetą. Nenuostabu, kad jos yra daug turtingesnés už ES šalis. OECD duomenimis, BNP per capita keturiose EFTA šalyse yra dvigubai didesnis už ES ${ }^{\prime \prime 37}$. Ar tokia perspektyva nebūtų viliojanti 'naujajai' Europai?

Žlugus referendumui dẻl ES konstitucijos Prancūzijoje ir Nyderlanduose, o vẻliau britams pradëjus maištą dèl ES biudžeto tapo akivaizdu, kad Europa yra susiskaidžiusi ne tik saugumo, bet ir ekonominės politikos klausimais. ES viršūniu susitikimas Briuselyje 2005 m. birželio 16-17 d. virto „mūšio lauku“, kur susikirto skirtingos politinès ir ekonominės Europos ateities vizijos. Galima svarstyti klausimą, ar Vidurio ir Rytų europiečiai nori (gali) užkirsti kelią Vokietijos ir Prancūzijos mėginimams sukurti antiamerikietišką ES ekonominę politiką. Ar ju proamerikanizmas saugumo klausimu gali transformuotis į anti-ES (antivokiškają ir antiprancūziškają) nuostatą ekonominès politikos klausimais? Ar jie drįstų palaikyti britu pusę prieš „,branduolio“ Europą? Ar gali pagrindinès Europos partijos, pradedant dešiniaisiais Vokietijoje, Italijoje ir Lenkijoje ir baigiant kairiaisiais Švedijoje, Ispanijoje ir Lietuvoje, susiburti aplink T. Blairą, kaip potencialu naujosios Europos vizijos - politiškai mažiau ambicingos, bet ekonomiškai dinamiškesnès - vèliavnešį? Nèra paprastų atsakymų i šiuos klausimus.

"Naujieji“ europiečiai gali pasirinkti oportunistinę strategiją mėgindami

${ }_{35}^{35}$ "Ich habe Angst um Europa“ [I am afraid for Europe], interview mit Vaclav Klaus, Frankfurter Allgemeine Zeitung, 15032005.

${ }^{36}$ Laar M., „New Europe Won't 'Keep Quiet' Until All Europe Is New“, The Wall Street Journal, February 19, 2003.

${ }^{37}$ Hannan D., ",The EU can work for Britain - if we quit", The Daily Telegraph, 28082005. 
įtikti abiem skilimo pusėms ir taip laimèti kokius nors nedidelius prizus. Tai būtų ịprastoji grupinių interesų politika, dažnai duodanti nulinės sumos arba negatyvios sumos rezultatus. Atrodo, kad tai yra vyraujanti pozicija dabartinëje Lietuvos užsienio politikoje ${ }^{38}$. Naivia viltimi grindžiama ir Lietuvos „ilgalaikès“ ekonominès politikos prognozė: „Lietuva, jau būdama ES senbuve” ir ",modernizavusi ūkio strategiją ir valstybės ekonominę politiką bei naudodamasi ES finansine ir technine parama”, bus iš esmés realizavusi „ES socialinį ekonominį modelį - gerovės valstybės, kurioje nedidelis nedarbas, aukšta darbo kaina, stiprios socialinės garantijos ir aukštas socialinės sanglaudos lygis ${ }^{\prime 39}$. Alternatyvus pasirinkimas - užimti principinę reformistinę poziciją ES atžvilgiu. Pasirinkimas priklauso nuo daugelio veiksniu, tarp jų nuo politinio sumanumo rezervu ir viešosios nuomonès būklès. Kalbant apie plačiają Lietuvos visuomenę reikia pripažinti, kad dar „per anksti daryti prognozes [...] dẻl jos vertybiu panašumo i Amerikoje arba Europoje vyraujančias vertybes, nes Lietuvos visuomenè tebėra perèjimo procese. [...] Viena vertus, reformu patirtis kai kuriose gyventoju grupèse išugde polinkị imtis rizikos ir šia prasme padarè juos panašius į amerikiečius. Kita vertus, vis dar stiprus prisirišimas prie paternalistinės valstybės, kuri, kaip rodo viešosios nuomonès apklausos, gali net sustiprèti bendraujant su Europos šalių visuomenėmis su jų išplètota valstybinės globos sistema"40. Tas pat pasakytina apie daugumą kitų ES naujokiu.

Bet kuriuo atveju po prancūzų ir olandu pasakyto "ne“ ES konstitucijai gilesnès politinės integracijos ir glaudesnès Europos viltis (arba baimė) gerokai išblèso. Kaip atrodo, šiuo metu ES paprasčiausiai dreifuoja. Kai kurioms šalims tai yra atokvėpio valandèlè nuo pavojaus, kad net tie Europos atkampiai, kurie atsilaikè prieš perteklinį ekonomikos reglamentavimą, bus galiausiai sureglamentuoti etatistiniu ES taisyklių ${ }^{41}$. Tai yra taip pat atokvépio valandėlè susimąstymui prieš priimant svarbius sprendimus. Yra taip pat šansu, kad Merkel ir Sarkozy,- du politiniai lyderiai, turintys neblogų šansų užimti aukščiausius politinius postus Vokietijoje ir Prancūzijoje,- gali būti labiau linkę pajudèti link ",anglosaksiškojo“ modelio. Tačiau neatrodo, kad jie pasižymi M. Thatcher arba R. Reagano ryžtingumu, kuris jiems padètu iveikti politinę inerciją. Be to, jiems tenka veikti socialinèje aplinkoje, kur ",pasidavimas neoliberalizmui“ yra anatema. Vis dèlto jie gali suteikti Europai atokvėpio valandèlę susivokti, jog nėra konstruktyvios alternatyvos anglosaksiškajam mažesnių mokesčiu, mažesnio valdžios išlaidavimo ir reglamentavimo modeliui. O suartëjus ekonominiams modeliams gali atsirasti daugiau šansų transatlantiniam skilimui užglaistyti.

\footnotetext{
38 Kaučikas N., „Prancūzai ieško sajungininku“, Veidas 30, 2005 m. liepos 28. Tačiau yra ir tu, kurie linksta prie britu pozicijos, žr.: „Lietuva ir naujoji Europa, kuriuo keliu žengsime? “ Veidas 27, $2005 \mathrm{~m}$. liepos 7.

${ }^{39}$ Lietuvos Respublikos Ūkio ministerija, Lietuvos mokslu akademija, Lietuvos ūkio (ekonomikos) pletros iki 2015 metu ilgalaike strategija, Vilnius, AB Vilspa, 2003, p. 20.

${ }^{40}$ Vilpišauskas R., „The Dilemmas of Transatlantic Relations after EU Enlargement and the Implications for Lithuania“, Lithuanian Foreign Policy Review 1-2(11-12), 2003, http:// www.lfpr.lt/latest.phtml.

${ }^{41}$ Išties naujausi kairiujų siūlomi Europos negalavimo gydymo receptai yra senas raugas: didesnè centralizacija, ",mokesčiu harmonizacija“ ir "perskirstymas žemyno mastu“; žr.: Blackburn R., "Capital and Social Europe“, New Left Review 34, July-August, 2005, p. 87 - 112.
} 


\section{Baigiamosios pastabos}

Apibendrinant galima pasakyti, jog transatlantinio skilimo priežastys yra iš esmès ideologinės ir jas nusako individualistinės ir kolektyvistinès pasaulèžiūros konfliktas sprendžiant įvairiausias vidaus politikos ir tarptautinès tvarkos problemas. Suvokus ši gilujį konfliktą lengviau suprasti daugelio nesutarimų tarp dviejų Atlanto pusių prigimtį. Saugumo ir grėsmių suvokimas, tarptautinių organizacijų vaidmens vertinimas, požiūris į nacionalizmą, ekonominès politikos uždaviniai - visos šios ir daugelis kitų problemų skirtingai interpretuojamos ir sprendžiamos dviejose Atlanto pusėse dèl jose vyraujančiu skirtingų ideologiju. Vidurio ir Rytų Europos šalys jau padare savo indėlį užkirsdamos kelią 'branduolio' Europai primesti visai Europai antiamerikietišką užsienio politiką. Atrodo, kad dabar joms atsiveria 'galimybės langas' pastūmèti Europą į suartëjimą su Amerika socialinès ir ekonominès politikos klausimais. Neišnaudodamos šios progos jos rizikuoja ne tik pasigauti pirmalaikę 'eurosklerozès' ligą, bet ir paaukoti savo saugumo interesus. Iššūkis, su kuriuo jos susiduria, yra didžiulis, tačiau nèra nepakeliamas.

Vilnius, 2005 m. rugsëjo 15 d. 